\title{
A Fossil Bone of a Giant Ground Sloth from the Last Millennium of the Pleistocene: New Data from Salto Department, Uruguay
}

\author{
Hugo G. Nami' ${ }^{1}$ Karina V. Chichkoyan², Mario Trindade³, José L. Lanata ${ }^{4}$ \\ ${ }^{1}$ Department of Geological Sciences, Laboratory of Geophysics “Daniel A. Valencio”, CONICET-IGEBA, FCEN, UBA, Buenos \\ Aires, Argentina \\ ${ }^{2}$ CONICET, Geographic Research Institute, National University of Luján, Luján, Buenos Aires, Argentina \\ ${ }^{3}$ Museum of Archeology and Natural Sciences, Salto, Uruguay \\ ${ }^{4}$ Institute for Research in Cultural Diversity and Processes of Change, CONICET-UNRN, Bariloche, Argentina \\ Email:hgnami@fulbrightmail.org
}

How to cite this paper: Nami, H. G. Chichkoyan, K. V., Trindade, M., \& Lanata, J. L. (2020). A Fossil Bone of a Giant Ground Sloth from the Last Millennium of the Pleistocene: New Data from Salto Department, Uruguay. Archaeological Discovery, 8, 295-310.

https://doi.org/10.4236/ad.2020.84017

Received: August 19, 2020

Accepted: October 18, 2020

Published: October 21, 2020

Copyright $\odot 2020$ by author(s) and Scientific Research Publishing Inc. This work is licensed under the Creative Commons Attribution International License (CC BY 4.0).

http://creativecommons.org/licenses/by/4.0/

\begin{abstract}
During the Pleistocene-Holocene transition at $\sim 10.0$ uncalibrated, or $\sim 11.7$ calibrated kya, the Americas were undoubtedly inhabited by humans from north to south ends. The groups living in that time had cultural and adaptive differences in terms of subsistence and technological pursuits. Particularly in the southern cone of South America, archaeological remains witnessed hunter-gatherers living at $\sim 11.0-10.0$ uncalibrated kya. They mostly used the so-called "fishtail," or just "Fell" points, a widespread Paleo-American marker. Despite that, they exploited different faunal species, including extant and extinct fauna. At the Salto Department in the northwestern region of Uruguay, on the Itaperibí Grande creek shore, archaeological remains of bones and stones were recovered. One of the most remarkable is a fragmented fossil femur of Lestodon armatus, a mega-mammal giant ground sloth. In its anterior face, this specimen shows diverse kinds of marks. However, no clear association among the findings was documented. Then, in order to check the possible relationship between the bone and the artifacts, the specimen was subjected to radiocarbon dating and it was analyzed in detail from a taphonomic perspective to evaluate the origin of the marks. The radiocarbon assay indicates that the specimen belongs to the last millennium of the Pleistocene. The date is relevant as it is one of the few assays obtained on a sample from that time. The taphonomic study revealed that the marks were not produced by human activity, hence, its primary relationship with the stone artifacts is uncertain. Despite that, these data make an important contribution to the knowledge about the fauna contemporaneously living with the earliest hunt-
\end{abstract}


er-gatherer that were foraging the regional landscape during one of the colonization events that populated the southern cone of South America.

\section{Keywords}

Fossil Bone, Lestodon armatus, Taphonomy, Radiocarbon Date, Late Pleistocene, South America

\section{Introduction}

Diverse lines of investigations indicate that the human colonization of the Americas occurred during the Late Pleistocene, but in a time that is subject to debate (Meltzer, 2009; 2013). However, growing archaeological evidence suggests that this process occurred at $\sim 14,000-15,000$ uncalibrated radiocarbon years before present or $\sim 14.0$ - 15.0 kya (Waters et al., 2011, 2018; Dillehay et al., 2017; Davis et al., 2017, 2019; among others), and probably earlier (Ardelean et al., 2020). From a planetary point of view, during the last millennium of the Pleistocene and its transition to the Holocene at $\sim 10.0$ uncalibrated, or $\sim 11.7 \mathrm{ca}$ librated kya (Walker et al., 2009, 2012, 2018; Gibbard \& Head, 2010; Head \& Gibbard, 2015) significant environmental and socio-cultural phenomena took place (e.g. Strauss et al., 1996; Dolukhanov, 1997; Acosta et al., 2018; Strauss 2018; among many others). Specially during the time of the Younger Dryas (Lothrop et al., 2011), the Americas were undoubtedly inhabited by hunter-gatherer groups in its entire territory from north to south ends (Lanata et al., 2008; Graf, 2013; Nami, 2014, 2020; Potter et al., 2018). The evidence provided by the archaeological record shows that there were cultural and adaptive differences in terms of subsistence and technological pursuits (Dillehay, 2009; Meltzer, 2009; Politis et al., 2008; 2019; Nami, 2014, 2019; Chichkoyan et al., 2017). Particularly in the southern cone of South America, the archaeological remains attest that foragers living 11.0 - 10.0 uncalibrated kya used the "fishtail," "Fell's cave," or "Fell" points (FP), a widespread Paleo-American (PA) marker. Probably originated in eastern North America (Nami, 2020), this distinctive lithic artifact had an extraordinary dispersion from Mesoamerica to the southern tip of South America (Bell, 1965; Bird \& Cooke, 1978; Mayer-Oakes, 1986; García-Barcena, 1980; Ranere \& Cooke, 2003; Nami, 2014, 2020). In spite of sharing similar projectile point shapes, the subsistence of the human groups using FPs in the southern cone exploited different faunal species, some of them now living, but also others that are now extinct (Salemme \& Miotti, 2008, Nami, 2014, 2019; Politis et al., 2019).

Located in northwestern Uruguay, the Museo de Arqueología y Ciencias Naturales (Salto city) conducted various field-work activities over the last decades. Among the remarkable results was the discovery of several archaeological and paleontological sites. As a contribution to the knowledge of the regional past, the 
finding of a significant fossil is reported, which was found useful to know about issues related to the coeval fauna of the early hunter-gatherers living during the terminal Pleistocene at Salto Department (Figure 1).

\section{The Paleontological Finding and General Remarks}

Conducted for different purposes, the field-work allowed the discovery of archaeological and paleontological remains on the shore of the Itaperibí Grande Creek ( $\left.31^{\circ} 19^{\prime} 09^{\prime \prime} \mathrm{S}, 57^{\circ} 34^{\prime} 53^{\prime \prime} \mathrm{W}\right)$. Belonging to the drainage basin of the Uruguay River, this watercourse, born in the Daymán hills, flows westerly in the reservoir formed by the Salto Grande dam on the Uruguay River. On its shore, and eroded from its banks, a number of archaeological and paleontological remains were found. The latter includes several extinct taxa; among them, two bones stood out because of their different kinds of marks on their surfaces. One of the most noticeable is the specimen reported in this paper, a fragmented fossil femur of Lestodon armatus (Xenarthra, Mammalia). The Lestodon armatus is an extinct species of megafaunal ground sloth that inhabited South America (e.g. Deschamps et al., 2000, Czerwonogora, 2010; Fariña et al., 2014, Ubilla et al., 2016; among others). Lestodon is placed as a member of the Mylodontinae monophyletic group.

According to the last phylogenetic study (Boscaini et al., 2019), it was a bulk-feeding mega-mammal, measuring $~ 4.5$ meters from nose to tail tip (Figure 2) and estimated to have weighed over 2 tons (Fariña et al., 2014). Remains of this kind of ground sloth were found in the Pleistocene deposits of Venezuela, Brazil, Bolivia, Paraguay, Argentina and Uruguay (Czerwonogora, 2010; Fariña et al., 2014), but some records date back to the Early Pliocene in Argentina (Deschamps et al., 2000). Particularly in northern Uruguay, the Lestodon armatus bones come from the Sopas Formation, a Late Pleistocene continental unit
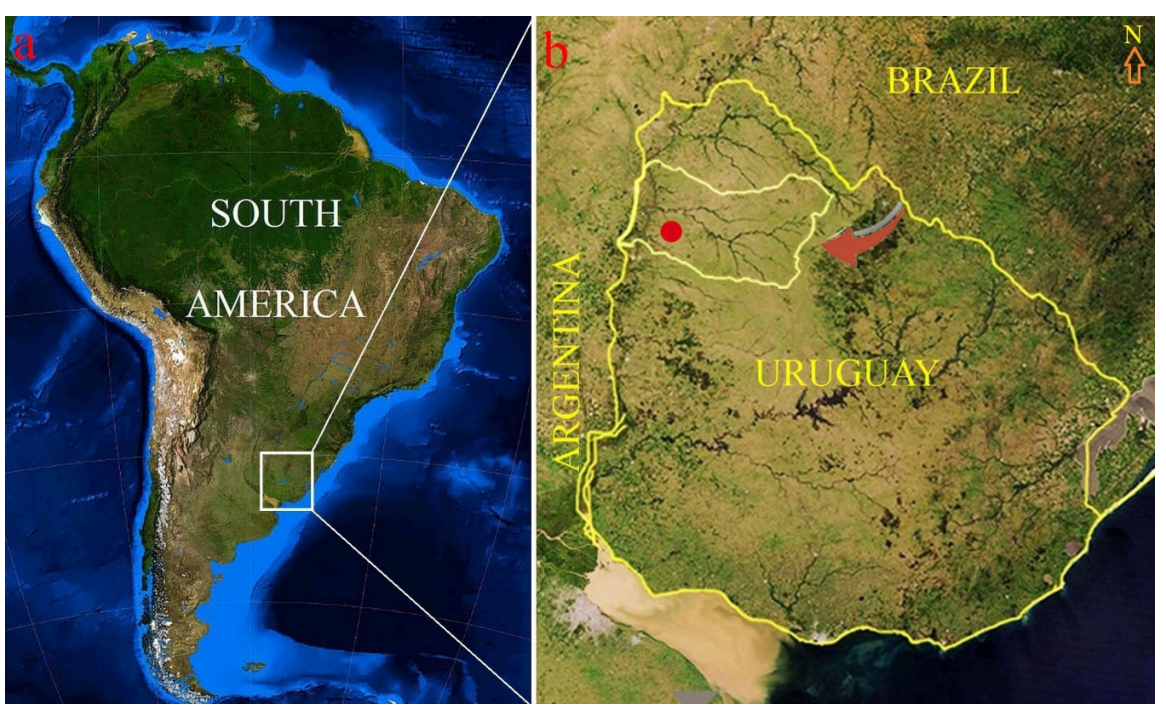

Figure 1. (a) Map of South America and the location of the Uruguay Republic denoted with a rectangle, (b) Salto Department within Uruguay indicated with an arrow and the Itaperibí creek showed with a red circle. Modified after NASA and Google Maps. 
including trace fossils, woods, fresh-water mollusks, and as illustrated in Figure 3, vertebrates with mammals as the predominant taxa (Ubilla et al., 2016, Table 4).
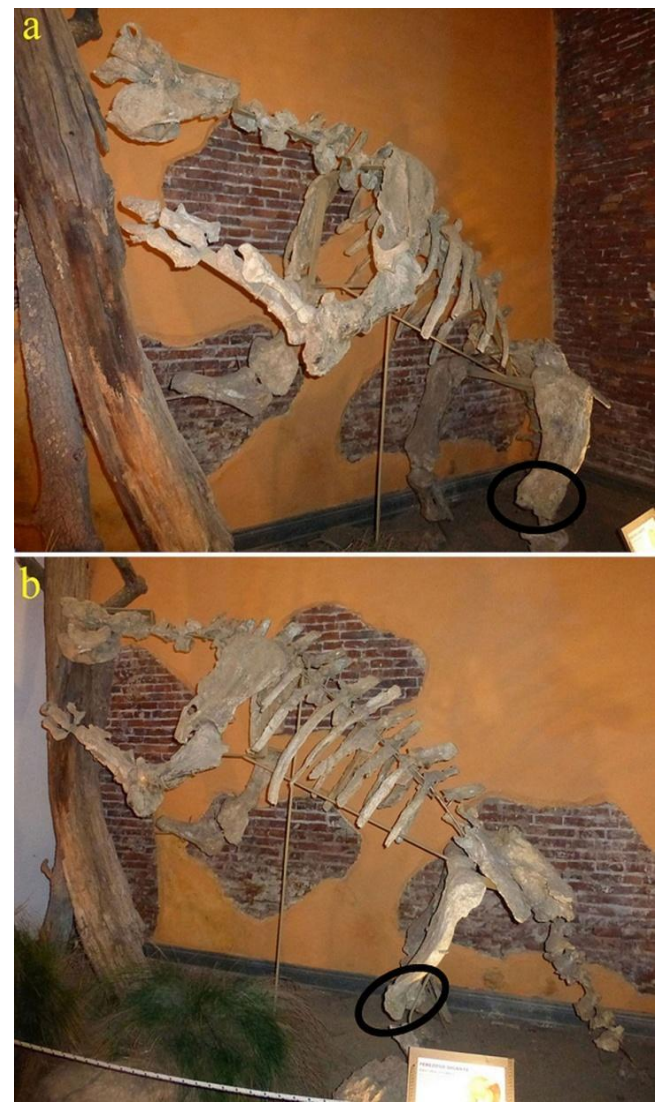

Figure 2. Mounted skeleton of Lestodon armatus displayed at the Paleontological Museum "Fray Manuel de Torres in the city of San Pedro (Buenos Aires, Argentina). (a). Frontal view, (b). Lateral view. The oval indicates the position of the femur studied here (Photos taken by K. V. Chichkoyan).

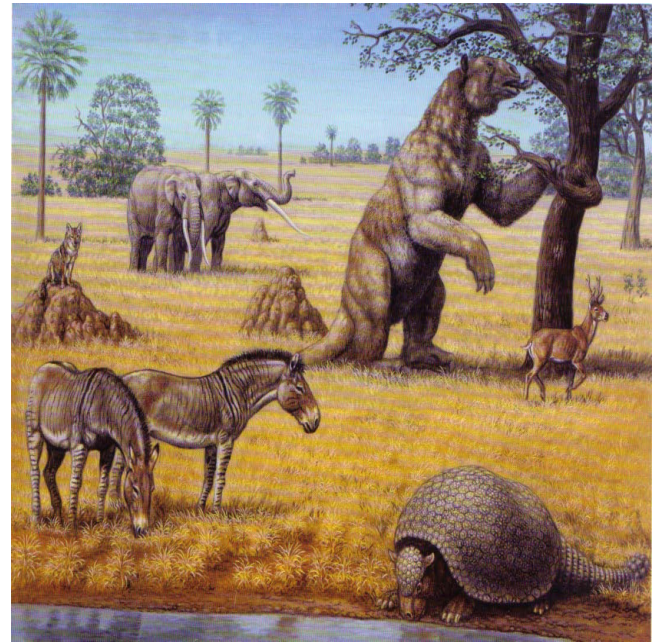

Figure 3. Late Pleistocene faunal composition of the Pampean region (region extended among Argentina, Uruguay and Brazil): Glyptodon, Megatherium, Equus and Prosbocidea. Drawing performed by Mauricio Antón (after Belinchón et al. 2009). 
At present, no clear associations between the findings have been documented. Then, in order to check the possible associations between the bones and the artifacts, one of the fossil remains was subject to radiocarbon dating and it was analyzed in detail from a taphonomic point of view so as to evaluate the marks origins. The results of this research are as follows.

\section{Taphonomic Observations}

This analysis was performed to describe the general state of the analyzed specimen and to identify possible anthropical intervention. As a discipline, taphonomy helps to detect and interpret the various agents affecting the living organisms following death (Lyman, 1994; Fernández-Jalvo \& Andrews, 2016). In this case, the most important agents to describe this fossil femur are:

1) Fresh and post-depositional fractures. bones can fracture just after an animal death or long after its skeleton gets exposed (Fernández-Jalvo \& Andrews, 2016). In the first case, the bone is still fresh and plastic. Therefore, borders will tend to be smooth, rounded, or curved. In the second case, the bone is already dry and lacks most of the collagen that tempers the impacts. As a consequence, borders will tend to be irregular and rough, with straight angles (Fernández-Jalvo \& Andrews, 2016).

2) Trampling: Abrasion of sediments over bones, given the movement of animals and/or humans, may generate lines and scratches (Lyman, 1994; Domínguez-Rodrigo et al., 2009). These are characterized by being randomly oriented and shallow, producing a general polishing and microabrasion over the bone surface (Olsen \& Shipman, 1988; Domínguez-Rodrigo et al., 2009). Nevertheless, they may also have straight orientation and have symmetrical or asymmetrical grooves, depending on the particle size and orientation (Domínguez-Rodrigo et al., 2009).

3) Weathering: Atmospheric conditions may produce changes in the surface of exposed bones. The sun, wind, or contrasting temperatures may result in cracking, exfoliation, flaking, splintering, and in later stages, the decomposition. A total or partial burial may affect parts of the same bone in different ways (Fernández-Jalvo \& Andrews, 2016).

4) Ancient cut marks and recent marks. Cut marks are generally characterized by being elongated/straight and narrow linear incisions (Lyman, 1994; Fisher Jr., 1995; Domínguez-Rodrigo et al., 2009), with V-shape walls and internal microstriations (Lyman, 1994; Fisher Jr., 1995; Fernández-Jalvo \& Andrews, 2016). They will tend to be present as patches or clusters of marks with parallel or similar orientation (Merritt, 2015) and to be related with specific anatomical position (Lyman, 1994; Domínguez-Rodrigo et al., 2009). Ancient cut marks can be differentiated from recent ones (generally done during excavation or manipulation), as fresh marks will have a lighter color than the surrounding surface (Fisher Jr., 1995).

Based on the characteristics mentioned above, in general, the analyzed femur 
fragment is in a good state of preservation. We detected different types of agents but no one related to an anthropic intervention. The presence of irregular and rough borders in the diaphysis indicates that the bone was fractured when the skeleton was exposed. The lighter borders of the anterior face (Figure 4(a)) are more recent than the posterior ones (Figure $4\left(\mathrm{a}^{\prime}\right)$ ), as the different coloration indicates fractures that were not subject to similar burial effects. Superficial, superpose, and non-oriented marks distributed along the shaft can be related to trampling activity (Figure 4(b)). The general polished aspect can also be related to this agent. Some cracking grooves along the long axis of the bone might have been produced by some surface exposure, at least in this area, producing this weathering effect (Figure 4(c)). Four diagonal (three large and one short), straight and parallel marks were also detected (Figure 4(d)). They have a lighter color than the rest of the bone, showing a recent exposure of the sub-cortical surface and indicating their recent origin, as it happened with the afore-described post-depositional fracture. These marks were made with the horseshoe of the horse the person who discovered this bone was riding. Besides, over the articular surface, two pre-depositional straight U-shape lines were detected (Figure 4(e)). Nevertheless, their orientation, lack of internal microstriations, and morphology dismiss an anthropogenic origin. So far, the origin of these marks is still unclear. They might be either the product of trampling, surface exposure, or even anatomical features of this species.

\section{Radiocarbon Dating}

To obtain its precise age, a small portion of the previously described femur was taken out for radiocarbon dating. The sample was submitted and processed by

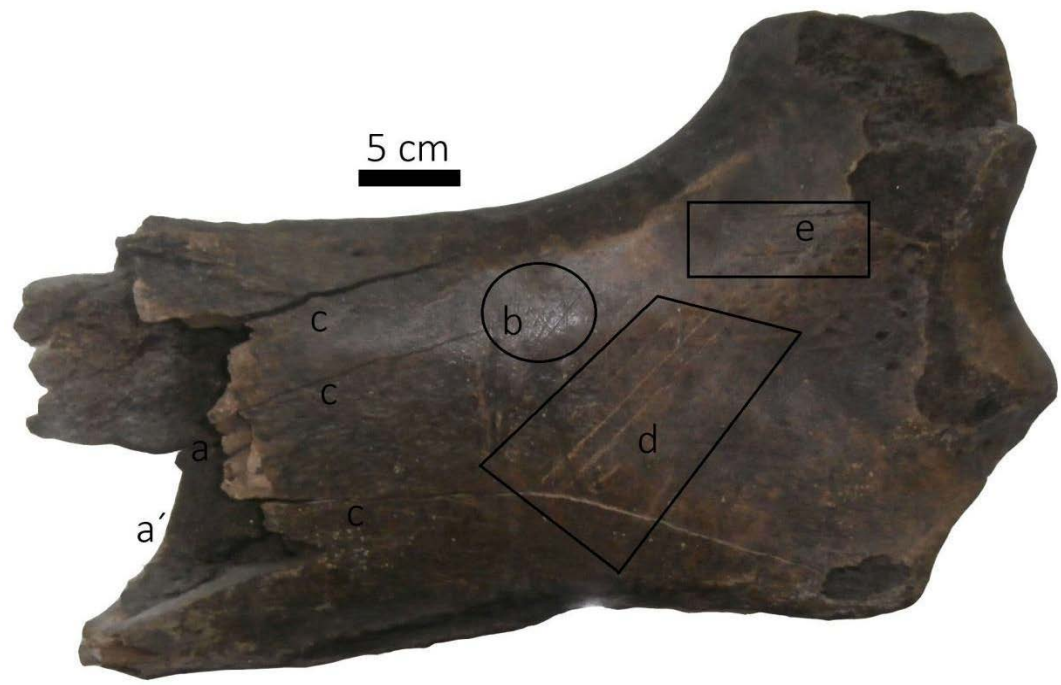

Figure 4. Anterior-distal view of Lestodon armatus fossil bone with the indication of the taphonomic agents described in the text: (a). Fresh post-depositional fracture, (a'). Ancient post-depositional fracture, (b). Trampling, (c). Weathering grooves, (d). Horseshoe's marks, (e). Unidentified ancient marks (Image credits H. G. Nami and K. V. Chichkoyan). 
analyzing the extracted collagen with alkali by Beta Analytic Inc. (Miami, Flori$\mathrm{da}, \mathrm{USA}$ ). The $\mathrm{C} / \mathrm{N}$ ratio of 3.3 indicates good collagen preservation as it is in the range of 2.9 to 3.6 that is considered reliable (De Niro, 1985; Ambrose, 1990). Using the AMS method, a Conventional Radiocarbon Age of $10820 \pm 40 \mathrm{BP}{ }^{14} \mathrm{C}$ yr BP (Beta - 469089) was obtained. This date was corrected by using the BetaCal 3.21 program based on the probability method developed by Bronk Ramsey (2009), and the ShCal 13 curve for the southern hemisphere (Hogg et al., 2013). Table 1 shows the results of the calibrated ages with $68.2 \%$ and $95.4 \%$ probability, and Figure 5, the calibrated age histogram.

Few direct taxon dates were obtained from this species inhabiting the Pampean and Uruguayan plains. In Argentina, an early assay of $16440 \pm 320{ }^{14} \mathrm{C}$ yr BP was from the Pehuén-Có locality, situated in the Atlantic coast (Aramayo et al., 2005). Figini and colleagues (1998) reported a standard date of $10710 \pm 90$ ${ }^{14} \mathrm{C}$ yr BP (LP-152) over a Pseudolestodon bone from Tapalqué creek. Earliest ages, on several Lestodon bones of circa 30,000 yr BP are from the Vizcaíno creek site, located in the southern area of Uruguay (Czerwonogora et al., 2011). Specially, the Tapalque creek date is almost contemporary with the one presented here. Remarkably, these dates show coeval populations of this taxon along the plains of Uruguay and Argentina, and coexisting with the first human population inhabiting this landscape.

Table 1. Range of calibrated ages for the Itaperibí creek date.

\begin{tabular}{ccccc}
\hline Uncalibrated age & \multicolumn{2}{c}{$68.2 \%$ probability } & \multicolumn{2}{c}{$95.4 \%$ probability } \\
\hline Years BP & Years BC & Years BP & Years BC & Years BP \\
\hline $10,820 \pm 40$ & $10,773-10,736$ & $12,722-12,685$ & $10,794-10,717$ & $12,743-12,666$ \\
\hline
\end{tabular}

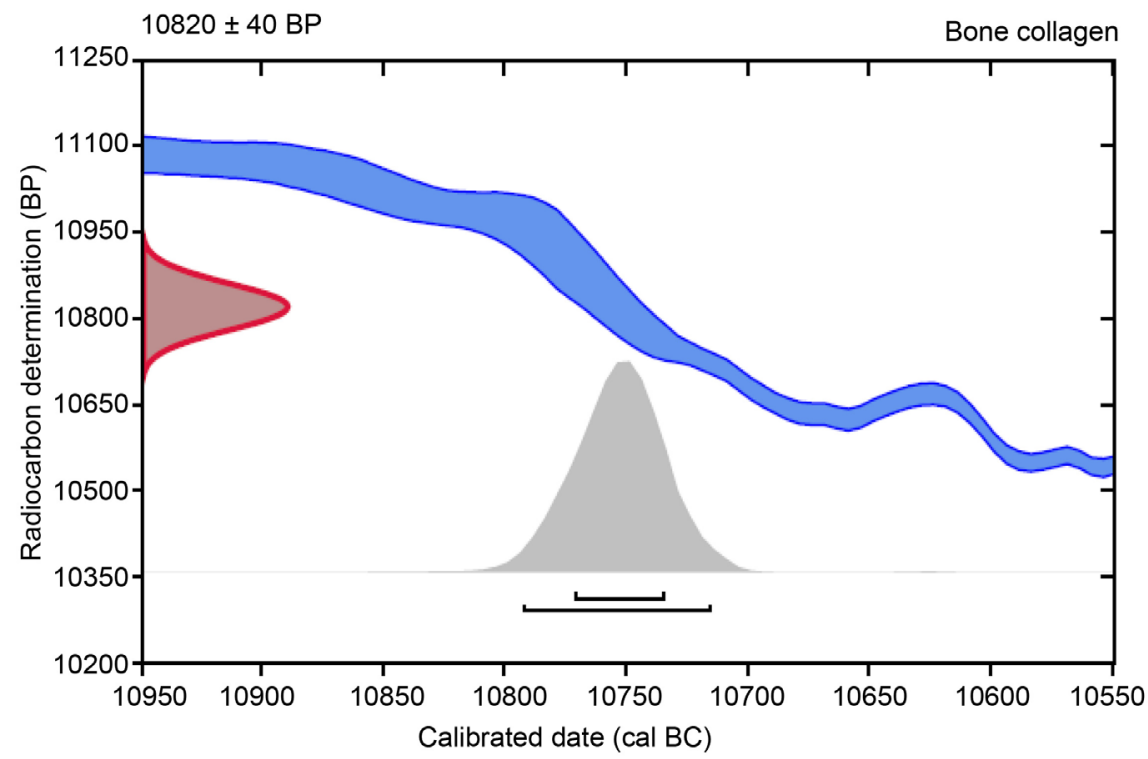

Figure 5. Plot showing the AMS date of $10,820 \pm 40 \mathrm{BP}{ }^{14} \mathrm{C}$ yr BP (Beta - 469089) for the Itaperibí Grande creek, as well as the $95.4 \%$ and $68.2 \%$ probability calibrated age ranges and the ShCal13 curve for the southern hemisphere (from Beta Analytic Inc.). 
The laboratory report also presents the first carbon $\left(\delta^{13} \mathrm{C}\right)$ and nitrogen $\left(\delta^{15} \mathrm{~N}\right)$ isotope values for Lestodon during the last millennium of the Pleistocene: -14.7 $\delta^{13} \mathrm{C}$ and $9.9 \delta^{15} \mathrm{~N}$. $\delta^{13} \mathrm{C}$ value is more enriched (less negative) than the ones reported for the Vizcaíno creek, while $\delta^{15} \mathrm{~N}$ is very similar (Czerwonogora et al., 2011). Intermediate $\delta^{13} \mathrm{C}$ and high $\delta^{55} \mathrm{~N}$ values might be related with grasses and some shrubs/trees vegetation in a predominant arid/semi-arid environment, as reflected in other isotopic studies of the Pampean region (Czerwonogora et al., 2011; Bocherens et al., 2016, 2017; Loponte \& Corriale, 2019), although more information is necessary to correctly interpret these results.

\section{Concluding Remarks}

To sum up, new data obtained from the Lestodon fossil bone from northwestern Uruguay have led to a more in-depth understanding of several topics. The taphonomic study demonstrated that the marks were not produced by human activity, and hence its primary relationship with the stone artifacts is uncertain. The radiocarbon date and isotope values are relevant because it is one of the few assays obtained directly on a sample from Lestodon armatus with age spanning the last millennium of the Pleistocene. Besides, it primarily belongs to the FPs' timeframe in South America in general, and the southern cone in particular (e.g., Jackson et al., 2007; Nami, 2007, 2017, 2019; Maggard \& Dillehay, 2011; Prates et al., 2013; Nami \& Stanford, 2016; Nuñez et al., 1994; Waters et al., 2015; Yataco Capcha \& Nami, 2016). Consequently, the information presented is not only significant from a paleontological point of view, but also from an archaeological and anthropological perspective. From the former, it is one of the few taxon dates belonging to this time for this extinct animal in the area. It also agrees with the fact that several South American giant ground sloths died out during the Late Pleistocene-Early Holocene extinction, an event that eliminated most large mammals in the Americas (e.g. Barnosky et al., 2004; Haynes, 2009; Prescott et al., 2012). The precise timing of this event during the terminal Pleistocene, and the onset of the Holocene is poorly understood in South America, primarily due to a lack of radiometric dates on taxa (Prevosti \& Schubert, 2013). Then, the data presented here shed light on this matter. More interestingly, it agrees with additional ages obtained in other species of extinct fauna in the Uruguayan territory (Meneghin \& Sánchez, 2009; Ubilla et al., 2018). Archaeologically, it absolutely matches with radiocarbon assays for the earliest regional human occupations (Miller, 1987, Meneghin, 2004, Suárez, 2017; Nami, 2017; Nami et al., 2018), suggesting in this way that at least this kind of mega-mammals was coeval with Paleo South Americans hunter-gatherers living in the region. Extremely important were the isotopic values. They contributed to the analysis and knowledge of the environment these foragers lived in. The date also agrees with the remarkable record of FPs existing in Southern Brazil, NE Argentina, and Uruguay (e.g. Bosch et al., 1980, Nami, 2013, 2017, 2020; Loponte et al., 2015, 2016; Loponte \& Carbonera, 2017; among others), whose examples are illustrated in Figure 6. It is worth mentioning that nearby the Itaperibí Grande creek, it is 


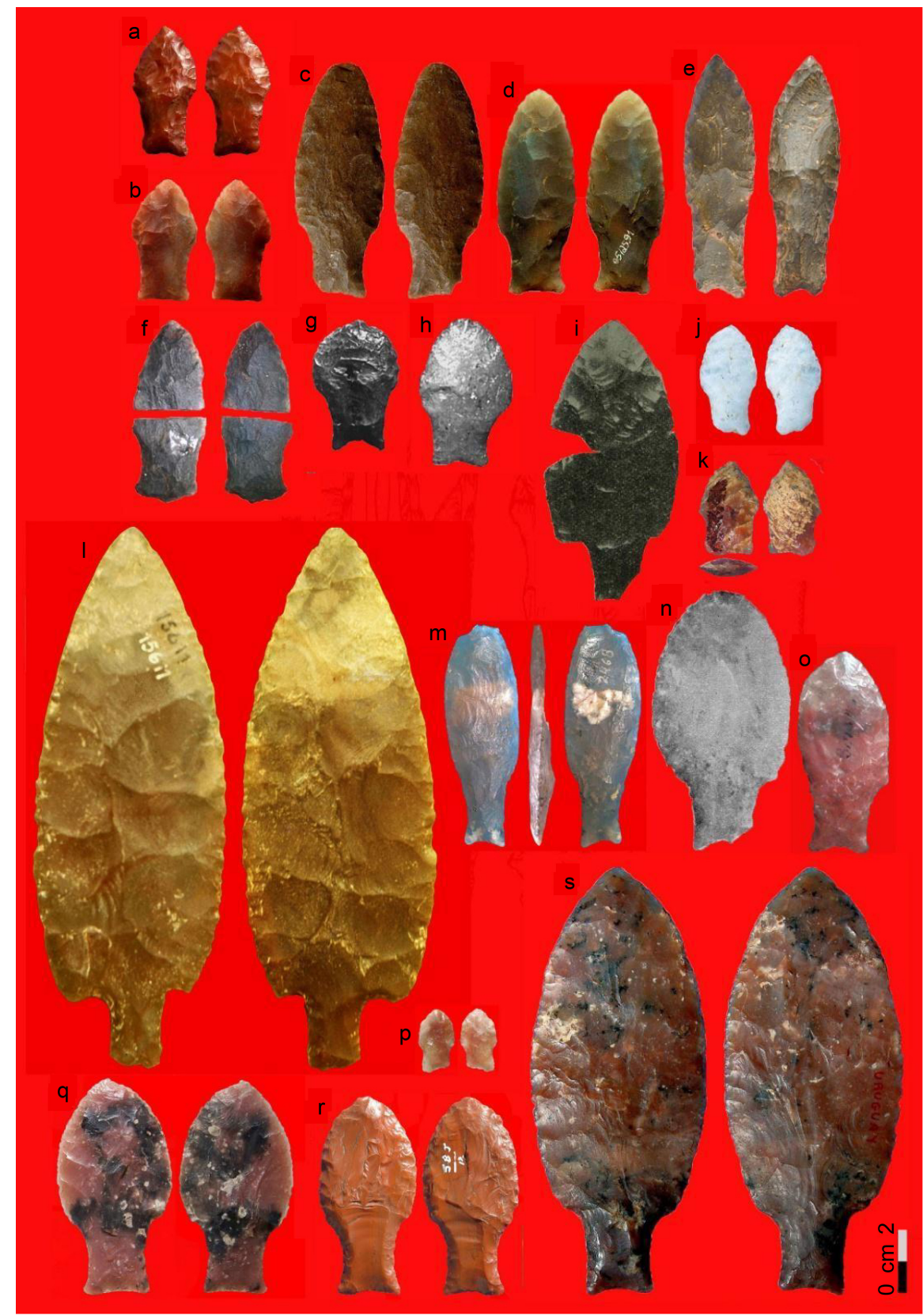

Figure 6. Illustrative examples of Fell points from southern Brazil ((a)-(d)), northeastern Argentina ((e)-(j)), and Uruguay ((k)-(s)), mainly from the Salto department ((k), (m)-(o)) and the Negro River drainage basin ((p)-(s)). They came from the following sites, localities and/or provinces: (a) Jusante UHE Salto Caixas I site; (b) Irani River; (c) Jaguaruna 11 site; (d) Montenegro site; (e) El Dorado, and (f) Puerto Esperanza, Misiones province; (g)-(h) nearby Monte Caseros, and (i) Santa Lucía site, Corrientes province, (j) Colonia Santa Eloísa, Federación, Entre Ríos province, (k) Barranca Pelada del Arapey, (l) Puntas del Queguay, Paysandú department, and (m)-(o) Boicuá creek, Salto Department; (p) San Gregorio de Polanco, (q) unknown site from the Tres Arboles creek basin, (r)-(s) Rincón del Bonete dam area, Photo credits: (r)-(s) U. Meneghin; (g)-(h), (k)-(m), (o)-(q) H. G. Nami. The remaining were modified after: (a)-(c) Loponte et al. 2015: Figure 3, Figure 5 and Figure 6; (d) da Silva Lopes and Nami 2011: Figure 1); (e)-(f) Loponte \& Carbonera 2017: Figure 4; (j) Capeletti 2011; (i) Serrano 1932: Lam. XV, 11; (n) Cordero 1960. Note: (n)-(o) not in scale. 
claimed that other types of projectile points belonging to different "techno-complexes" overlap the time of the FPs from other South American areas (Suárez, 2017). However, needless to say, that this data must be taken with caution in light of alluvial geo-archaeology and site formation processes (Nami, 2013, Feathers \& Nami, 2018), principally in the Uruguay River (Pouey Vidal, 2018). Finally, due to the scarcity of this sort of finds, its discovery deserves attention, mainly because it makes an important contribution to the knowledge about the fauna contemporaneously living with the earliest hunter-gatherers that were foraging the regional landscape during the last millennium of the Pleistocene.

\section{Acknowledgements}

We are indebted to CONICET (National Scientific and Technical Research Council) (CONICET) and UBA (University of Buenos Aires) for their continuous support of our investigations; we gratefully acknowledge grants from ANPCyT, Argentina (PICT-2014-1558), and G. Páez Reina for helping us to make the map of Uruguay.

\section{Conflicts of Interest}

The authors declare no conflicts of interest regarding the publication of this paper.

\section{References}

Acosta, G., Beramendi, L., González Hernández, G., Rivera, I., Eudave, I., Hernández, E., Sánchez Pérez, S. Morales Puente, P., Cienfuegos Alvarado, E., \& Otero, F. J. (2018). Climate Change and Peopling of the Neotropics during the Pleistocene-Holocene Transition. Boletín de la Sociedad Geológica Mexicana, 70, 1-19. https://doi.org/10.18268/BSGM2018v70n1a1

Ambrose, S. H. (1990). Preparation and Characterization of Bone and Tooth Collagen for Isotopic Analysis. Journal of Archaeological Science, 17, 431-451. https://doi.org/10.1016/0305-4403(90)90007-R

Aramayo, S. A., Gutiérrez Téllez, B., \& Schillizzi, R. A. (2005). Sedimentologic and Paleontologic Study of the Southeast Coast of Buenos Aires Province, Argentina: A Late Pleistocene-Holocene Paleoenvironmental Reconstruction. Journal of South American Earth Sciences, 20, 65-71. https://doi.org/10.1016/j.jsames.2005.05.002

Ardelean, C. F., Becerra-Valdivia, L., Pedersen, M. W. et al. (2020). Evidence of Human Occupation in Mexico around the Last Glacial Maximum. Nature, 584, 87-92. https://doi.org/10.1038/s41586-020-2509-0

Barnosky, A. D., Koch, P. L., Feranec, R. S., Wing, S. L., \& Shabel, A. B. (2004). Assessing the Causes of late Pleistocene Extinctions on the Continents. Science, 306, 70-75. https://doi.org/10.1126/science.1101476

Belinchón, M., Peñalver, E., Montoya, P., \& Gascó, F. (2009). Crónicas de Fósiles. Las Colecciones paleontológicas del Museo de Ciencias Naturales de Valencia. Valencia: Ayuntamiento de Valencia. Regidoría de Cultura.

Bell, R. (1965). Archaeological Investigations at the Site El Inga, Ecuador. Quito: Casa de 
Cultura.

Bird, J., \& Cooke, R. (1978). Los artefactos más antiguos de Panamá. Revista Nacional de Cultura, 6, 7-29.

Bocherens, H., Cotte, M., Bonini, R. A., Straccia, P., Scian, D., Soibelzon, L., \& Prevosti, F. J. (2017). Isotopic Insight on Paleodiet of Extinct Pleistocene Megafaunal Xenarthrans from Argentina. Gondwana Research, 48, 7-14. https://doi.org/10.1016/j.gr.2017.04.003

Bocherens, H., Cotte, M., Bonini, R., Scian, D., Straccia, P., Soibelzon, L., \& Prevosti, F. J. (2016). Paleobiology of Sabretooth Cat Smilodon populator in the Pampean Region (Buenos Aires Province, Argentina) around the Last Glacial Maximum: Insights from Carbon and Nitrogen Stable Isotopes in Bone Collagen. Palaeogeography, Palaeoclimatology, Palaeoecology, 449, 463-474. https://doi.org/10.1016/j.palaeo.2016.02.017

Boscaini, A., Pujos, F., \& Gaudin, T. J. (2019). A Reappraisal of the Phylogeny of Mylodontidae (Mammalia, Xenarthra) and the Divergence of Mylodontine and Lestodontine Sloths. Zoologica Scripta, 48, 691-710. https://doi.org/10.1111/zsc.12376

Bosch, A., Femenías, J., \& Olivera, A. (1980). Dispersión de las puntas líticas pisciformes en el Uruguay. III Congreso Nacional de Arqueología, Anales, Montevideo: CEA.

Bronk Ramsey, C. (2009). Bayesian Analysis of Radiocarbon Dates. Radiocarbon, 51, 337-360. https://doi.org/10.1017/S0033822200033865

Capeletti, L. E. (2011). Primer hallazgo de una punta de proyectil "Cola de Pescado" en la provincia de Entre Ríos. Libro de resúmenes del VI Congreso de Arqueología de la Región Pampeana, Revista del Museo de La Plata. Arqueología, 12, 66R-67R.

Chichkoyan, K. V., Martínez-Navarro, B., Moigne, A.-M., Belinchón, M., \& Lanata, J. L. (2017). The Exploitation of Megafauna during the Earliest Peopling of the Americas: An Examination of Nineteenth-Century Fossil Collections. Comptes Rendus Palevol, 16, 440-451. https://doi.org/10.1016/j.crpv.2016.11.003

Cordero, S. (1960). Los charrúas. Montevideo: Editorial Mentor.

Czerwonogora, A. (2010). Morfología, sistemática y paleobiología de los perezosos gigantes del género Lestodon Gervais 1855 (Mammalia, Xenarthra, Tardigrada). La Plata: Universidad Nacional de la Plata, Facultad de Ciencias Naturales y Museo.

Czerwonogora, A., Fariña, R. A., \& Tonni, E. P. (2011). Diet and Isotopes of Late Pleistocene Ground Sloths: First Results for Lestodon and Glossotherium (Xenarthra, Tardigrada). Neues Jahrbuch für Geologie und Paläontologie-Abhandlungen, 262, 257-266. https://doi.org/10.1127/0077-7749/2011/0197

da Silva Lopes, L., \& Nami, H. G. (2011). A New Fishtail Point Find from South Brazil. Current Research in the Pleistocene, 28, 104-107.

Davis, L. G., Bean, D. W., \& Nyers, A. J. (2017). Morphometric and Technological Attributes of Western Stemmed Tradition Projectile Points Revealed in a Second Artifact Cache from the Cooper's Ferry Site, Idaho. American Antiquity, 82, 536-557. https://doi.org/10.1017/aaq.2017.9

Davis, L. G., Madsen, D. B., Becerra-Valdivia, L., Higham, T., Sisson, D. A., Skinner, S. M., Stueber, D., Nyers, A. J. et al. (2019). Late Upper Paleolithic Occupation at Cooper's Ferry, Idaho, USA, 16,000 Years Ago. Science, 365, 891-897.

https://doi.org/10.1126/science.aax9830

De Niro, M. J. (1985). Postmortem Preservation and Alteration of In-Vivo Bone Collagen Isotope Ratios in Relation to Palaeodietary Reconstruction. Nature, 317, 806-809. https://doi.org/10.1038/317806a0

Deschamps, C. M., Esteban, G. I., \& Bargo, M. S. (2000). El registro más antiguo del género Lestodon Gervais, 1855 (Xenarthra, Tardigrada, Mylodontidae) (Montehermosense, 
Plioceno Temprano). Ameghiniana, 38, 51-156.

Dillehay, T. D. (2009). Probing Deeper into First American Studies. Proceedings of the National Academy of Sciences of the United States of America, 106, 971-978. https://doi.org/10.1073/pnas.0808424106

Dillehay, T. D., Goodbred, S., Pino, M., Vásquez Sánchez, V. F. et al. (2017). Simple Technologies and Diverse Food Strategies of the Late Pleistocene and Early Holocene at Huaca Prieta, Coastal Peru. Science Advances, 3, 1-13.

Dolukhanov, P. M. (1997). The Pleistocene-Holocene Transition in Northern Eurasia: Environmental Changes and Human Adaptations. Quaternary International, 41-42, 181-191. https://doi.org/10.1016/S1040-6182(96)00051-1

Domínguez-Rodrigo, M., De Juana, S., Galán, A. B., \& Rodríguez, M. (2009). A New Protocol to Differentiate Trampling Marks from Butchery Cut Marks. Journal of Archaeological Science, 36, 2643-2654. https://doi.org/10.1016/j.jas.2009.07.017

Fariña, R. A., Czerwonogora, A., \& Di Giacomo, M. (2014). Splendid Oddness: Revisiting the Curious Trophic Relationships of South American Pleistocene Mammals and Their Abundance. Anais da Academia Brasileira de Ciências, 86, 311-331. https://doi.org/10.1590/0001-3765201420120010

Feathers, J., \& Nami, H. G. (2018). Luminescence Dating of Late Pleistocene and Holocene Sediments in Uruguay. Latin American Antiquity, 29, 495-513. https://doi.org/10.1017/laq.2018.9

Fernández-Jalvo, Y., \& Andrews, P. (2016). Atlas of Taphonomic Identifications. 1001+ Images of Fossil and Recent Mammal Bone Modification. The Netherlands: Springer. https://doi.org/10.1007/978-94-017-7432-1

Figini, A., Fidalgo, F., Huarte, R., Carbonari, J., \& Tonni, E. P. (1998). Edades C-14 en un perfil del Arroyo Tapalqué, provincia de Buenos Aires, Argentina. Contribución a la cronología de acontecimientos faunístico-ambientales. Actas del X Congreso Latinoamericano de Geología y VI Congreso Nacional de Geología Económica, 1, 27-31.

Fisher Jr., J. W. (1995). Bone Surface Modifications in Zooarchaeology. Journal of Archaeological Method and Theory, 2, 7-68. https://doi.org/10.1007/BF02228434

García-Barcena, J. (1980). Una Punta Acanalada de la Cueva de los Grifos, Ocozocoautla, Chiapas. Cuaderno de Trabajo del Departamento de Prehistoria No. 17, Mexico DF: Instituto Nacional de Antropologia e Historia.

Gibbard, P. L., \& Head, M. J. (2010). The Newly-Ratified Definition of the Quaternary System/Period and Redefinition of the Pleistocene Series/Epoch, and Comparison of Proposals Advanced Prior to Formal Ratification. Episodes, 33, 152-158. https://doi.org/10.18814/epiiugs/2010/v33i3/002

Graf, K. E. (2013). Siberian Odyssey. In K. Graf, C. V. Ketron, \& M. R. Waters (Eds.), Paleoamerican Odyssey (pp. 65-80). College Station, TX: Texas A\&M University.

Haynes, G. (Ed.) (2009). American Megafaunal Extinctions at the End of the Pleistocene. The Netherlands: Springer. https://doi.org/10.1007/978-1-4020-8793-6

Head, M. J., \& Gibbard, P. L. (2015). Formal Subdivision of the Quaternary System/Period: Past, Present, and Future. Quaternary International, 383, 4-35. https://doi.org/10.1016/j.quaint.2015.06.039

Hogg, A. G., Quan, H., Blackwell, P. G., Mu, N., Buck, C. E., Guilderson, T. P., Heaton, T. J., Palmer, J. G., Reimer, P. J., Reimer, R. W., Turney, C. S., \& Zimmerman, S. R. H. (2013). SHCal13 Southern Hemisphere Calibration, 0 - 50,000 Years cal BP. Radiocarbon, 55, 1889-1903. https://doi.org/10.2458/azu js rc.55.16783

Jackson, D., Méndez, C., Seguel, R., Maldonado, A., \& Vargas, G. (2007). Initial Occupa- 
tion of the Pacific Coast of Chile during Late Pleistocene Times. Current Anthropology, 48, 725-731. https://doi.org/10.1086/520965

Lanata, J. L., Martino, L., Osella, A., \& Garcia-Herbst, A. (2008). Demographic Conditions to Colonize New Spaces: The Early Human Dispersal in the Americas Case. World Archaeology, 40, 520-537. https://doi.org/10.1080/00438240802452890

Loponte, D., \& Carbonera, M. (2017). Paleoamericans in Northeast Argentina. Archaeological Discovery, 5, 79-94. https://doi.org/10.4236/ad.2017.52005

Loponte, D., \& Corriale, M. J. (2019). Patterns of Resource Use and Isotopic Niche Overlap among Guanaco (Lama guanicoe), Pampas Deer (Ozotoceros bezoarticus) and Marsh Deer (Blastocerus dichotomus) in the Pampas. Ecological, Paleoenvironmental and Archaeological Implications. Environmental Archaeology, 1-34.

https://doi.org/10.1080/14614103.2019.1585646

Loponte, D., Carbonera, M., \& Silvestre, R. (2015). Fishtail Projectile Points from South America: The Brazilian Record. Archaeological Discovery, 3, 85-103. https://doi.org/10.4236/ad.2015.33009

Loponte, D., Okumura, M., \& Carbonera, M. (2016). New Records of Fishtail Projectile Points from Brazil and Its Implications for Its Peopling. Journal of Lithic Studies, 3, 63-85. https://doi.org/10.2218/jls.v3i1.1312

Lothrop, J. C., Newby, P. E., Spiess, A. E., \& Bradley, J. W. (2011). Paleoindians and the Younger Dryas in the New England-Maritimes Region. Quaternary International, 242, 546-569. https://doi.org/10.1016/j.quaint.2011.04.015

Lyman, R. L. (1994). Vertebrate Taphonomy. In Cambridge Manuals in Archaeology. Cambridge: Cambridge University Press. https://doi.org/10.1017/CBO9781139878302

Maggard, G. J., \& Dillehay, T. (2011). El Palto Phase (13800-9800 BP). In T. Dillehay (Ed.), From Foraging to Farming in the Andes: New Perspectives on Food Production and Social Organization (pp. 77-94). Cambridge: Cambridge University Press. https://doi.org/10.1017/CBO9780511793790.005

Mayer-Oakes, W. (1986). Early Man Projectile Points and Lithic Technology in the Ecuadorean Sierra. In A. Bryan (Ed.), New Evidence for the Pleistocene Peopling of the Americas (pp. 281-294). Orono, ME: Center for the Study of the Early Man.

Meltzer, D. J. (2009). First Peoples in a New World: Colonizing Ice Age America. Berkeley, CA: University of California Press. https://doi.org/10.1525/9780520943155

Meltzer, D. J. (2013). The Human Colonization of the Americas: Archaeology. In I. Ness (Ed.), The Encyclopedia of Global Human Migration (Vol. 1). New York: Blackwell. https://doi.org/10.1002/9781444351071.wbeghm808

Meneghin, U. (2004). URUPEZ. Primer registro radiocarbónico (C-14) para un yacimiento con puntas líticas pisciformes del Uruguay. Orígenes, 2, 1-30.

Meneghin, U., \& Sánchez, A. (2009). Hallazgo de artefactos líticos y megafauna en el cauce de los arroyos Vejigas y Pilatos (Depto. de Canelones, Uruguay). Orígenes, 8, $1-24$.

Merritt, S. R. (2015). Cut Mark Cluster Geometry and Equifinality in Replicated Early Stone Age Butchery. International Journal of Osteoarchaeology, 26, 585-598. https://doi.org/10.1002/oa.2448

Miller, E. T. (1987). Pesquisas arqueológicas paleoindígenas no Brasil Ocidental. Estudios Atacameños, No. 8, 39-64. https://doi.org/10.22199/S07181043.1987.0008.00005

Nami, H. G. (2007). Research in the Middle Negro River Basin (Uruguay) and the Paleoindian Occupation of the Southern Cone. Current Anthropology, 48, 164-176.

https://doi.org/10.1086/510465 
Nami, H. G. (2013). Archaelogy, Paleoindian Research and Lithic Technology in the Middle Negro River, Central Uruguay. Archaeological Discovery, 1, 1-22. https://doi.org/10.4236/ad.2013.11001

Nami, H. G. (2014). Arqueología del último milenio del Pleistoceno en el Cono Sur de Sudamérica, puntas de proyectil y observaciones sobre tecnología Paleoindia en el Nuevo Mundo. In M. Farias, \& A. Lourdeau (Eds.), Peuplement et Modalités d'Occupation de l'Amérique du Sud: L'Apport de la Technologie Lithique (pp. 279-336). Prigonrieux: @rchéo-éditions.com and Impr. Copy-média.

Nami, H. G. (2017). Silcrete as a Valuable Resource for Stone Tool Manufacture and Its Use by Paleo-American Hunter-Gatherers in Southeastern South America. Journal of Archaeological Science: Reports, 15, 539-560.

https://doi.org/10.1016/j.jasrep.2016.05.003

Nami, H. G. (2019). Paleoamerican Occupation, Stone Tools from the Cueva del Medio, and Considerations for the Late Pleistocene Archaeology in Southern South America. Quaternary, 2, 28. https://doi.org/10.3390/quat2030028

Nami, H. G. (2020). Fishtailed Projectile Points in the Americas: Remarks and Hypotheses on the Peopling of Northern South America and Beyond. Quaternary International, in press. https://doi.org/10.1016/j.quaint.2020.06.004

Nami, H. G., \& Stanford, D. J. (2016). Dating the Peopling of Northwestern South America: An AMS Date from El Inga Site, Highland Ecuador. PaleoAmerica, 2, 60-63. https://doi.org/10.1080/20555563.2016.1139793

Nami, H. G., Florines, A., \& Toscano, A. (2018). New Paleoindian Finds, Further Fell Points Data, and Technological Observations from Uruguay: Implications for the Human Peopling in Southeastern South America. Archaeological Discovery, 6, 21-37. https://doi.org/10.4236/ad.2018.61002

Nuñez, L., Casamiquela, R., Schiappacasse, V., Niemeyer, H., \& Villagrán, C. (1994). Cuenca de Taguatagua en Chile: El ambiente del pleistoceno y ocupaciones humanas. Revista Chilena de Historia Natural, 67, 503-519.

Olsen, S. L., \& Shipman, P. (1988). Surface Modification on Bone: Trampling versus Butchery. Journal of Archaeological Science, 15, 535-553.

https://doi.org/10.1016/0305-4403(88)90081-7

Politis, G. G., Messineo, P. G., Stafford Jr., T. W., \& Lindsey, E. L. (2019). Campo Laborde: A Late Pleistocene Giant Ground Sloth Kill and Butchering Site in the Pampas. Science Advances, 5, eaau4546. https://doi.org/10.1126/sciadv.aau4546

Politis, G., Prates, L., \& Perez S. (2008). El Poblamiento de América. Arqueología y bío-antropología de los primeros americanos. Buenos Aires: EUDEBA.

Potter, B. A., Baichtal, J. F., Beaudoin, A. B., Fehren Schmitz, L., Haynes, C. V., Holliday, V. T., Holmes, C. E., Ives, J. W., Kelly, R. L., Llamas, B., Malhi, R. S., Shane Miller, D., Reich, D., Reuther, J. D., Schiffels, S., \& Surovell, T. A. (2018). Current Evidence Allows Multiple Models for the Peopling of the Americas. Science Advances, 4, eaat5473. https://doi.org/10.1126/sciadv.aat5473

Pouey Vidal, V. (2018). La Ocupación Cazadora-Recolectora durante la Transición Pleistoceno-Holoceno en el Oeste de Rio Grande do Sul-Brasil: Geoarqueología de los Sitios en la Formación Sedimentaria Touro Passo. Oxford: Archaeopress Publishing Ltd.

Prates, L., Politis, G., \& Perez, S. (2013). Radiocarbon Chronology of the Early Human Occupation of Argentina. Quaternary International, 301, 104-122. https://doi.org/10.1016/j.quaint.2013.03.011

Prescott G. W., Williams, D. R., Balmford, A., Green, R. E., \& Manica, A. (2012). Quan- 
titative Global Analysis of the Role of Climate and People in Explaining Late Quaternary Megafaunal Extinctions. Proceedings of the National Academy of Sciences of the United States of America, 109, 4527-4531. https://doi.org/10.1073/pnas.1113875109

Prevosti, F. J., \& Schubert, B. W. (2013). First Taxon Date and Stable Isotopes $\left(\delta^{13} \mathrm{C}, \delta^{15} \mathrm{~N}\right)$ for the Large Hypercarnivorous South American Canid Protocyon troglodytes (Canidae, Carnivora). Quaternary International, 305, 67-73.

https://doi.org/10.1016/j.quaint.2012.07.003

Ranere, A. J., \& Cooke, R. (2003). Late Glacial and Early Holocene Occupation of Central American Tropical Forests. In J. Mercader (Ed.), Under the Canopy. The Archaeology of Tropical Rain Forests (pp. 219-248). New Brunswick: Rutgers University Press.

Salemme, M., \& Miotti, L. (2008). Archaeological Hunter-Gatherer Landscapes Since the Latest Pleistocene in Fuego-Patagonia. In J. Rabassa (Ed.), The Late Cenozoic of Patagonia and Tierra del Fuego (pp. 437-483). New York: Elsevier.

https://doi.org/10.1016/S1571-0866(07)10022-1

Serrano, A. (1932). Exploraciones arqueológicas en el río Uruguay medio. Paraná: Talleres gráficos Casa Predassi.

Strauss, L. G. (2018). Environmental and Cultural Changes across the Pleistocene-Holocene Transition in Cantabrian Spain. Quaternary International, 465, 222-233.

https://doi.org/10.1016/j.quaint.2016.10.005

Strauss, L. G., Eriksen, B. V., Erlandson, J., \& Yesner, D. R. (Eds.) (1996). Humans at the End of the Ice Age: The Archaeology of the Pleistocene-Holocene Transition. New York: Springer.

Suárez, R. (2017). The Human Colonization of the Southeast Plains of South America: Climatic Conditions, Technological Innovations and the Peopling of Uruguay and South of Brazil. Quaternary International, 431, 181-193.

https://doi.org/10.1016/j.quaint.2016.02.018

Ubilla, M., Corona, A., Rinderknecht, A., Perea, D., \& Verde, M. (2016). Marine Isotope Stage 3 (MIS 3) and Continental Beds from Northern Uruguay (Sopas Formation): Paleontology, Chronology, and Climate. In G. M. Gasparini, J. Rabassa, C. Deschamps, \& E. P. Tonni (Eds.), Marine Isotope Stage 3 in Southern South America, 60 KA B.P.-30 KA B.P(pp. 183-206). Cham: Elsevier. https://doi.org/10.1007/978-3-319-40000-6 11

Ubilla, M., Rinderknecht, A., Corona, A., \& Perea, D. (2018). Mammals in Last 30 to 7 ka Interval (Late Pleistocene-Early Holocene) in Southern Uruguay (Santa Lucía River Basin): Last Occurrences, Climate, and Biogeography. Journal of Mammalian Evolution, 25, 291-300. https://doi.org/10.1007/s10914-017-9380-2

Walker, M. J. C., Berkelhammer, M., Bjorck, S., Cwynar, L. C., Fisher, D. A., Long, A. J., Lowe, J. J., Newnham, R. M., Rasmussen, S. O., \& Weiss, H. (2012). Formal Subdivision of the Holocene Series/Epoch: A Discussion Paper by a Working Group of INTIMATE (Integration of Ice-Core Marine and Terrestrial Records) and the Subcommission on Quaternary Stratigraphy (International Commission on Stratigraphy). Journal of Quaternary Science, 27, 649-659. https://doi.org/10.1002/jqs.2565

Walker, M., Head, M. J., Berkelhammer, M., Björck, S., Cheng, H., Cwynar, L., Fisher, D., Gkinis, V., Long, A., Lowe, J., Newnham, R., Rasmussen, S. O., \& Weiss, H. (2018). Formal Ratification of the Subdivision of the Holocene Series/Epoch (Quaternary System/Period): Two New Global Boundary Stratotype Sections and Points (GSSPs) and Three New Stages/Subseries. Episodes, 41, 213-223.

https://doi.org/10.18814/epiiugs/2018/018016

Walker, M., Johnsen, S., Rasmussen, S. O., Steffensen, J. P., Popp, T., Gibbard, P., Hoek, 
W., Lowe, J., Bjorck, S., Cwynar, L., Hughen, K., Kershaw, P., Kromer, B., Litt, T., Lowe, D. J., Nakagawa, T., Newnham, R., \& Schwander, J. (2009). Formal Definition and Dating of the GSSP (Global Stratotype Section and Point) for the Base of the Holocene Using the Greenland NGRIP Ice Core and Selected Auxiliary Records. Journal of Quaternary Science, 24, 3-17. https://doi.org/10.1002/jqs.1227

Waters, M. R., Amorosi, T., \& Stafford, T. (2015). Redating Fell's Cave, Chile and the Chronological Placement of the Fishtail Projectile Point. American Antiquity, 80, 376-386. https://doi.org/10.7183/0002-7316.80.2.376

Waters, M. R., Forman, S. L., Jennings, T. A., Nordt, L. C., Driese, S. G., Feinberg, J. M., Keene, J. L., Halligan, J., Lindquist, A., Pierson, J., Hallmark, C. T., Collins, M. B., \& Wiederhold, J. E. (2011). The Buttermilk Creek Complex and the Origins of Clovis at the Debra L. Friedkin Site, Texas. Science, 331, 1599-1603.

https://doi.org/10.1126/science.1201855

Waters, M. R., Keene, J. L., Forman, S. L., Prewitt, E. R., Carlson, D. L., \& Wiederhold, J. E. (2018). Pre-Clovis Projectile Points at the Debra L. Friedkin Site, Texas-Implications for the Late Pleistocene Peopling of the Americas. Science Advances, 4, eaat4505. https://doi.org/10.1126/sciadv.aat4505

Yataco Capcha, J., \& Nami, H. G. (2016). A Re-Evaluation of Paleo-American Artifacts from Jaywamachay Rockshelter, Ayacucho Valley, Peru. PaleoAmerica, 2, 368-372. https://doi.org/10.1080/20555563.2016.1199198 